Elżbieta Muskat-Tabakowska

Uniwersytet Jagielloński, Kraków

elzbieta.muskat-tabakowska@uj.edu.pl

\title{
PIES WIERNY, ALE UCIĄŻLIWY, CZYLI RZECZ O METAFORZE (LEŚMIANA I NIE TYLKO)
}

Słowa klucze: domena poznawcza, eksplikacja, językoznawstwo kognitywne, metafora, metafora obrazowa, metafora pojęciowa, podstawa, rozwinięcie, rzutowanie, tertium comparationis

Keywords: cognitive domain, explication, cognitive linguistics, metaphor, visual metaphor, conceptual metaphor, base, extension, projection, tertium comparationis

Jako miłośniczka poezji Leśmiana i badaczka języka zainteresowana metaforą sięgnęłam po monografię Wacława Cockiewicza Metaforyka Leśmiana (Analiza lingwistyczna) (Kraków 2011) w nadziei na interesującą i pouczającą lekturę: oto kolega po fachu postanowił się zmierzyć z nie byle jakim wyzwaniem, któremu wielu przed nim próbowało stawić czoło. Ale jeszcze wcześniej poszłam na wykład Autora, także poświęcony metaforyce Leśmiana. Tytuł, któremu przed prelekcją Autor nadał formę, jak to sam określił, „bardziej dramatyczną”, zawierał się w fundamentalnym pytaniu „Jak badać metaforę?". Celem wykładu była prezentacja rzeczonej monografii, a punkt wyjścia stanowiło stwierdzenie Autora, że choć teorii metafory jest dziś bardzo wiele, brak poświęconych jej prac analitycznych. O ile pierwszej części zdania trudno byłoby zaprzeczyć, o tyle dość trudno zgodzić się z częścią drugą - nie sięgając już do prac badaczy zagranicznych, warto wspomnieć chociażby o takich autorach, jak Elżbieta Wójcik-Leese, Agnieszka Libura, Dorota Korwin-Piotrowska czy Ewa Sławkowa.

Ponieważ wykład Wacława Cockiewicza - wygłoszony po trzech latach od ukazania się książki - był w zasadzie prezentacją zawartych w niej treści, poniższe komentarze 
odnoszę głównie do monografii, sygnalizując tylko te kwestie, w których od tamtego czasu Autor zmienił zdanie. Na wstępie wypada stwierdzić, że wbrew zdaniu otwierającemu rozważania Cockiewicza, jego książka JEST „jeszcze jedną książką o metaforze". Swój temat przedstawia zresztą Autor w formie pytania nie o to, jak badać metaforę, ale o to, „jaką rolę odgrywa metafora w poezji Leśmiana?” (s. 7). Natomiast $\mathrm{w}$ podsumowaniu zaprezentowanych czytelnikom analiz udziela na to pytanie odpowiedzi, stwierdzając, iż rola ta

[...] polega (...) na uzupełnianiu (inopiae causa) tych obszarów semantycznych, które nie mają swoich korelatów językowych - w przypadku metafory językowej w niemetaforycznym zasobie wyrażeń kodu naturalnego, w przypadku zaś subkodu poetyckiego w słownictwie i frazeologii (a po części też w gramatyce) języka standardowego. Metaforyka Leśmiana jest zatem [...] ważnym i systemowo zorganizowanym środkiem służącym do wzbogacenia języka (s. 230-231).

Powyższe stwierdzenie mówi o roli metafory „w ogóle” jako - jak pisze sam Autor „immanentnej cechy struktury języka” (s. 8), i trudno by się było w nim dopatrzeć charakterystycznych cech właściwych poezji Leśmiana. Można natomiast znaleźć przyczyny licznych wątpliwości, jakie rozważania Autora budzą u czytelnika - zwłaszcza u czytelnika zainteresowanego metaforą, a zwłaszcza - metaforą poetycką. Nie jest dla mnie na przykład jasne, czym jest dla Autora „niemetaforyczny zasób wyrażeń kodu naturalnego” w opozycji do „słownictwa i frazeologii” oraz „po części gramatyki” „języka standardowego". Jaka jest różnica między „kodem naturalnym” i „językiem standardowym"? Jak należałoby zdefiniować te dwa pojęcia? W teoretycznym wstępie do swoich analiz Cockiewicz przywołuje - za twórcami kognitywnej teorii metafory (Lakoff, Johnson 1980/1988) - ogólnie przyjmowaną opozycję między „dosłownym” i „przenośnym” charakterem wyrażeń językowych. Na podstawie tej opozycji tworzy

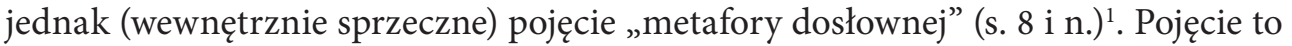
stosuje następnie w części analitycznej w odniesieniu do metafor, które (na ogół błędnie) uznaje za przypadki „tak zwanej metafory pojęciowej”. Zdaniem Autora metafora pojęciowa występuje „w repertuarze standardowym języka” (s. 8). Jest tak istotnie, choć nie tylko: jest to przecież efekt każdego rzutowania treści jednej domeny poznawczej na inną. A z tym Autor oczywiście się zgadza, choć określające metaforę pojęciową wyrażenie „tak zwana” podaje w wątpliwość trafność pojęcia podstawowego dla teorii kognitywnej, tym samym precyzując stanowisko Autora wobec tej teorii².

Zarzucając językoznawstwu kognitywnemu przyjmowanie konwencji, która rzekomo polega na rezygnacji z definiowania podstawowych pojęć (s. 9), Autor sam

1 Przywoływani autorzy mówią w tym kontekście o dosłownych wyrażeniach (expressions), a nie metaforach.

2 Nawiasem mówiąc, na s. 218 - w podobnie ironicznym tonie - mówi on o „filozofach języka”, błędnie zresztą utożsamiając ich z pragmalingwistami. 
wykazuje sporą terminologiczną beztroskę, zapewne w myśl zasady, którą explicite wyraża zwrotem „mniejsza o nazwę" (s. 17; notabene angielski termin vehicle Richardsa odpowiadający polskiemu określeniu nośnik jest konsekwentnie przywoływany z błędem ortograficznym). Jak już powiedzieliśmy, kognitywną teorię metafory (w wersji postulującej rzutowanie dwóch domen) Autor odrzuca jako nieprzydatną, choć czyni to, wychodząc z zasadniczo fałszywej przesłanki, jakoby teoria ta rozważała głównie

[...] częściowo uniwersalny, a częściowo typologiczny system pojęciowy zawarty $\mathrm{w}$ langue, podczas gdy stylistyczne badania materiałowe podjęte w [jego własnej - E. T.] pracy koncentrują się na tekście (literackim), a więc na dziedzinie parole (s. 20).

Tę niechęć do teorii kognitywnej trudno jednak w pełni zrozumieć w świetle następującego w dalszym ciągu stwierdzenia, że proponowany w jej ramach uniwersalny model „pozwala wyjaśniać istotę konkretnych wyrażeń metaforycznych spotykanych w poezji, retoryce, a także w języku potocznym" (s. 23, wyróżn. E. T.). Stawianie teorii kognitywnej zarzutu, że jej słabszą stroną jest „by tak rzec, aprioryczny kierunek wnioskowania: od intuicyjnie tworzonego modelu teoretycznego do przykładów potwierdzających jego adekwatność" (ibid.) świadczy o niezrozumieniu nie tylko fundamentalnych zasad językoznawczego kognitywizmu, ale także - w dziedzinie badań nad teorią metafory - o ignorowaniu roli, jaką odgrywają w nich badania korpusowe. Można też przypuszczać, że Autor nie uznaje wagi rozróżnienia między metaforą pojęciową (będącą efektem rzutowania między dwiema domenami poznawczymi) i metaforą obrazową (opartą na podobieństwie między dwoma obiektami) - dychotomii postulowanej już w klasycznej pracy George’a Lakoffa (1991). Stąd też zapewne przekonanie, że „teoria ta nie nadaje się jako podstawa teoretyczna do empirycznych badań nad metaforą w tekstach" (s. 27). Ponieważ jednak niektóre z założeń teorii metafory pojęciowej, zgodne z ogólnie przyjmowanymi twierdzeniami filozofii języka (np. nieostrość znaczenia czy biologiczne uniwersalia), pojawiają się implicite w tekście monografii, można przypuszczać, że gdyby Autor potraktował je w sposób bardziej pogłębiony i systematyczny, dostrzegłby zapewne ich zalety jako narzędzia analizy.

Ogólnie rzecz biorąc, teoretyczne rozważania zawarte w pierwszym rozdziale monografii wprowadzają spory dysonans poznawczy, rzutując tym samym na odbiór prezentowanych w dalszym ciągu treści. Na przykład, w efekcie terminologicznego zamieszania, metafora poetycka/kreatywna zostaje przez Autora przemianowana na metaforę tekstowa (przy czym nie musi to, jego zdaniem, być ani metafora „poetycka ani kreatywna”, s. 11), a następnie przeciwstawiona metaforze potocznej, definiowanej z kolei jako metafora „skrajnie (?) sfrazeologizowana”. Jest ona różna od metafory językowej, która ze swej strony zostaje utożsamiona z metafora pojęciową (s. 12). Graf mający zilustrować tę skomplikowaną klasyfikację (Rys. 1, s. 12) dodatkowo cały zamęt powiększa, ponieważ metafora potoczna pojawia się na nim jako podkategoria metafory tekstowej... 
Przyjęte w analizach założenia metodologiczne wskazują, że głoszone przez Autora kategoryczne odżegnywanie się od kognitywizmu nie jest uzasadnione - zwłaszcza w tych obszarach, gdzie kognitywna teoria metafory przyjmuje założenia niebudzące, zdaniem Autora, „istotnych kontrowersji”. Tak więc postulowane „metaforyczne zdania elementarne” to chyba nic innego jak metafory generyczne G. Lakoffa i Marka Turnera (1989), zaś terminy temat i nośnik, w takim ujęciu, w jakim występują w książce, dają się odnieść do pojęć domeny docelowej i domeny źródłowej (w teorii rzutowania pojęciowego między dwiema domenami - w odróżnieniu od nowszej teorii przestrzeni mentalnych i amalgamacji pojęciowej). Natomiast o ile odnalezienie tertium comparationis jest oczywiście warunkiem wstępnym interpretacji metafory, o tyle trudno się zgodzić - zapewne także niekognitywiście - że metafora

[...] stanowi bezpośrednie (metaforyczne zdania elementarne) lub pośrednie (inne wyrażenia metaforyczne, zwłaszcza werbalne (?)) stwierdzenie identyczności A i B (s. 28, wyróżn. E. T.).

Oczywiste jest - we wszystkich chyba rozważaniach dotyczących metafory, niezależnie od przyjmowanych ram teoretycznych - że rzutowanie metaforyczne ma charakter cząstkowy, a „podświetlanie” (higlighting) niektórych elementów domen podlegających rzutowaniu oznacza „usuwanie w cień” (backgrounding) innych. Metafora nie jest zatem relacją równoważności i stosowanie w części analitycznej formuł ze znakiem równości między tematem i nośnikiem $[A=B$; np. „istnienie = substancja materialna”, s. 79) jest całkowicie nieuzasadnione. Paradoksalnie, dostrzega to sam Autor, który w końcowej partii książki stwierdza, że „eksponowanie podstawy” przy równoczesnym „zignorowaniu wszelkich różnic między tematem a nośnikiem [...] stanowi zabieg dla metafory nie tylko typowy, ale wręcz konstytuujący" (s. 199). To oczywiście prawda. Gwoli prawdy należy też dodać, że w dyskusji po wspomnianym referacie Autor wycofał się z niefortunnego twierdzenia o identyczności tematu i nośnika, zastępując ową „identyczność” mniej nieuzasadnionym, choć bardziej mylącym, terminem quasi-identyfikacja.

W podsumowaniu swoich analiz Autor stwierdza, że w poezji Leśmiana metafora nie jest ani „doraźnym środkiem ornamentacyjno-stylistycznym”, ani „prostą funkcją metaforycznego charakteru języka w ogóle”, wykazuje natomiast „wyraźne cechy systemowości" (s. 204). Temu ostatniemu stwierdzeniu nie można odmówić słuszności, natomiast dowody trudno odnaleźć w gąszczu danych empirycznych, analizowanych w sposób, który trudno uznać za przekonujący i metodologicznie poprawny. Aby uzasadnić tę opinię, rozważmy podaną na s. 29 „przykładową jednostkę analizy". Mój wybór został podyktowany faktem, że tego samego przykładu Autor użył w referacie, można więc sądzić, że uważa go za szczególnie reprezentatywny. A więc metaforę odnalezioną (według jakiego kryterium? - mógłby w tym miejscu zapytać dociekliwy czytelnik) w wyrażeniu „Coś srebrnego dzieje się w chmur dali” sprowadza Autor do „metaforycznego zdania elementarnego”, zapisanego w postaci 
formuły $\underline{\text { AKCJA/ZDARZENIE }=\text { przedmiot materialny }}{ }^{3}$. Za podstawę tej metafory uznaje coś, co określa jako tertium comparationis sensu stricto i definiuje jako „punkt wyjścia polegający na istnieniu jakiegoś podobieństwa” między tematem i nośnikiem. Zakładając, że ta zawiła definicja oznacza, iż punktem wyjścia dla interpretacji metafory jest istnienie jakiegoś określonego podobieństwa, przechodzimy do dalszych partii analizy. Dowiadujemy się, że w analizowanym przykładzie ową podstawę stanowią

[...] wyrażenia potoczne, metaforyczne: dzieje się coś dziwnego, ciekawego, niedobrego, strasznego [...] etc., które gramatycznie, za pomocą leksemu adiektywnego, przypisują argumentowi zdarzeniowemu atrybuty przedmiotu (s. 30).

Przyznam, że bardzo trudno mi śledzić ten tok rozumowania. Czyżby zrozumienie wersu wyjętego z wiersza Szczęście polegało na przywołaniu przez odbiorcę analogii między analizowanym wyrażeniem i innymi znanymi mu (potocznymi) wyrażeniami językowymi? Czyż nie idzie tu raczej o rozumienie ogólnych pojęć akcji/zdarzenia i obiektu? Rozwinięciem metafory jest natomiast zdaniem Autora rozszerzenie podstawy podobieństwa „poprzez zabiegi różnego rodzaju: uogólnienie, uszczegółowienie, zmiany zakresu znaczeniowego (atrybutywności, predykatywności) etc." (ibid.). Niejako na marginesie wypada zauważyć że zarówno uogólnienie, jak uszczegółowienie także oznaczają zmianę zakresu znaczeniowego. Rozwinięciem jest natomiast w analizowanym przykładzie „rozszerzenie zakresu atrybutywności na inne przymioty właściwe przedmiotowi, np. kolor” (ibid.). Pomijając już implikowany przez kształt przy toczonej formuły brak rozróżnienia między akcją (czyli procesem) i zdarzeniem (czyli określoną relacją między jego uczestnikami), łatwo przecież zauważyć, że „coś, co się dzieje” jest standardowo reifikowane jako obiekt niematerialny, na co zresztą wskazują cytowane w tekście przymiotniki dziwne, ciekawe, niedobre, straszne... Ponadto - odwołując się do terminologii kognitywnej - cytowane wyrażenie stanowi jedną z podstawowych metafor struktury zdarzenia (zob. ZDARZENIA TO RUCHOME OBIEKTY, Evans 2009: 73), a więc jest ono przykładem metafory generycznej: w analizowanym fragmencie wiersza Leśmiana „to, co się dzieje” istotnie staje się (dzięki połączeniu z przymiotnikiem „srebrny”) „przedmiotem materialnym” i dopiero owa ogólna specyfikacja buduje uszczegółowioną metaforę: „,coś, co się dzieje w chmur dali, to ruchomy srebrny przedmiot".

Brak konsekwentnych założeń metodologicznych w połączeniu z przyjęciem kolejności alfabetycznej „tematów” jako zasady porządkującej obszerny materiał empiryczny powoduje pomieszanie metafor z różnych poziomów - generycznych (tj. ogólnych; w większości skonwencjonalizowanych) i obrazowych (tj. twórczych,

3 Tu i dalej metafory generyczne analizowane w monografii podano w oryginalnym zapisie. Według konwencji przyjętej w kognitywnej teorii metafory formuła ta miałaby kształt wyrażenia AKCJA/ ZDARZENIE TO PRZEDMIOT MATERIALNY. 
jednostkowych, okazjonalnie konwencjonalizowanych w postaci frazeologizmów). Tak więc na przykład, szczegółowa metafora ANIOE = człowiek (zidentyfikowana na podstawie wyrażenia „trup anioła”) pojawia się tuż przed ogólną metaforą generyczną ATRYBUT = proces, która zostaje zilustrowana przykładami kilku szczegółowych metafor obrazowych. Znajdujemy wśród nich, między innymi, wyrażenia „Czy w twych łzach się zazłocę? Czy się we mgle - zaniebieszczę?”. Przyjrzyjmy się więc ich eksplikacji. Otóż jako podstawę przyjmuje się w obu przypadkach „czasowniki derywowane od nazw kolorów" (s. 41). Nawiasem mówiąc, nasuwa się w tym miejscu pytanie, dlaczego tylko tę grupę czasowników, skoro polszczyzna zna derywaty typu „zdrewnieć” czy „skamienieć”. Jeszcze bardziej zaskakuje proponowane przez Autora rozwinięcie: z niewiadomego powodu „zazłocić się" i „zaniebieścić się" uważane są za „rozszerzenie [tego] wzorca derywacyjnego na inne atrybuty” (ibid.).

Wariant analizowanej metafory ATRYBUT $=$ proces, zapisany jako ATRYBUT $=$ przedmiot, ilustrują między innymi dwa fragmenty wierszy Leśmiana: „Słońce wsącza plamiście/ Bystrych świateł rozbryzganą rzadź” i „Kijem niegdyś wędrownym obłędnie się babrze/ W nieodlegle błękitnym - pełnym Boga - chabrze”. W pierwszym wypadku podstawę stanowi zdaniem Autora „metafora potoczna rzadkie światło”, rozwinięcie zaś - „metateza (obiektu i atrybutu)”. Pomijając już wątpliwy status wyrażenia „rzadkie światło” jako metafory potocznej (tego związku frazowego nie podają na przykład internetowe wyszukiwarki), „przedmiot” określany jako „rzadź” to przecież „rzadka substancja”, neologizm Leśmiana zaś powstał według istniejącego wzorca derywacyjnego ( gładki - gładź, spadać - spadź), co zresztą gwarantuje jego czytelność. Zapewne warto byłoby się w tym kontekście zastanowić nad różnicą między metaforą i neologizmem. Podobnych wątpliwości nie budzi drugi przytoczony przykład, w którym podstawą jest istotnie „kolor niebieski - atrybut wspólny dla chabru (sic!) i nieba" (s. 41). Natomiast stwierdzenie, że rozwinięciem tej metafory jest „identyfikacja [chabra i nieba] na podstawie wspólnego atrybutu” (ibid.) wypada pozostawić bez komentarza.

Pomieszanie poziomów procesu metaforyzacji prowadzi do licznych niekonsekwencji. Tak więc, na przykład, formuły BŁEKIT = trunek, alkohol oraz BŁE, BIT = woda, ciecz zostają zaklasyfikowane jako dwie odrębne metafory (s. 44-45); wyrażenie „bieg życia strumieni” uznaje się za realizację metafory $\mathrm{CZAS}^{4}$ = płynąca woda, rzeka (s. 61); w postulowanej metaforze MROK/CIEMNOŚĆ = żywa istota, człowiek, zwierzę, ptak (s. 97) wszystkie nośniki wymieniono „ciągiem”, tak jakby występowały na tym samym poziomie kategoryzacji, bez uwzględnienia „hierarchii bytów”; wyrażenie "noc... zabije" zinterpretowano jako realizację metafory $\mathrm{NOC}=$ śmierć, choć można by w tym miejscu zasadnie zapytać, dlaczego śmierć, a nie morderca? (s. 111), itd. Przykłady - wobec obfitości analizowanego materiału - można by mnożyć; wymienione powyżej stanowią zaledwie mały fragment długiej listy.

4 A nie, jak można by oczekiwać, ŻYCIE. 
W jednym - i tylko w jednym - wypadku czytelnik znajduje wyjaśnienie, że „autor manifestuje tu w sposób egzemplaryczny swój (tradycyjny) pogląd na istotę metafory" (s. 150, przypis 3). Można by przypuszczać, że uzasadnia on w ten sposób selektywność i tak już nader obszernego materiału - gdyby nie fakt, że jest to przypis będący uzupełnieniem eksplikacji jednej $z$ analizowanych metafor.

Metodologiczne niekonsekwencje maskuje stosowanie modulatorów typu „niekiedy” (s. 151) oraz bogactwo językoznawczej terminologii, czasem rozszerzanej poza przyjętą konwencję (por. „metateza obiektu i atrybutu”, s. 41). Zaproponowana na początku definicja podstawy (por. wyżej) powoduje bezradność Autora wobec niektórych metafor, zmuszając go do przyznania, że podstawa jest „niejasna” (por. np. s. 79, 89, 99). Zdarzają się eksplikacje, które wypada uznać za w sposób oczywisty błędne - np. opis leksemu błyszczydło („Sam go wywiódł z nicości błyszczydłami swych oczu"). Zdaniem Autora jest to ilustracja metafory PROCES = PRZEDMIOT, $\mathrm{z}$ rozwinięciem polegającym „na tym, że według tego modelu utworzony został jednak neologizm o znaczeniu abstrakcyjnej nazwy czynności” (s. 195; wyróżn. E. T.). Uzasadniając owo rozszerzenie faktem, że formant -idło jest wykładnikiem kategorii nomina instrumenti, czyli nazw narzędzi i środków czynności, na liście przykładów niemetaforycznych realizacji tego typu słowotwórczego Autor umieszcza derywaty straszydło i... świecidło.

Interpretacyjne dowolności najlepiej pokazuje eksplikacja zestawionych ze sobą dwóch metafor (obrazowych) $\underline{\text { ŚMIERĆ = pies i } \mathrm{i} Y \mathrm{YCIE}=\text { pies, }}$, odnalezionych $\mathrm{w}$ wierszu Leśmiana Śmierć Buddy. Pierwszą ilustruje przytoczony (s. 150) fragment

Śmierć opodal, we zgubne zwinięta pierścienie,

Czekała, jak pies wierny, na jego skinienie.

Uczył ją wlec obrożę i lizać złe pęta

I patrzał, jak w ślad za nim po snach się wałęta,

A dziś - choć się skłębiła nad wspólną otchłanią -

Nawet jej nie pogłaskał i nie spojrzał na nią...

Podkreślenia pochodzą od Autora. Przyznam, że nie wiem, dlaczego „Śmierć we zgubne zwinięta pierścienie" to pies, a nie na przykład jadowity wąż lub żmija, ani dlaczego skłębiony (?) pies miałby się „wałętać po snach”. Jako podstawę tej metafory podano „podstawę immanentną, użyte w tekście porównanie” (s. 150). Trudno mi się zgodzić ze stwierdzeniem, że tertium comparationis (a więc, jak chce, Autor, podstawą) metafory jest porównanie wykorzystujące te same dwie domeny pojęciowe.

Metaforę Ś SIERĆ = pies zestawia Autor $\mathrm{z}$ drugą, przedstawioną $\mathrm{w}$ postaci formuły

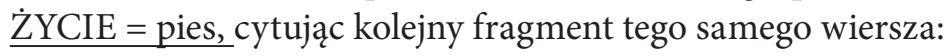

A gdziekolwiek poszedłem - szło za mną w krok życie,

Szło, skamląc o kęs ciała i tucząc się troską... (s. 186). 
Tym razem przyjmuje on za podstawę (czyli, przypomnijmy, za tertium comparationis) „porównanie śmierci do psa” z wcześniejszej analizy, po czym stwierdza, że rozszerzeniem jest w tym przypadku „konwers i pełna identyfikacja oparta na kontraście: śmierć - pies wierny i posłuszny, życie - pies wierny, ale uciążliwy” (s. 186). Ta partia wywodu pozostaje dla mnie całkowicie niezrozumiała.

Metafora okazuje się szczególnie oporna, jeśli - nie przyjmując zasad rządzących jej powstawaniem i interpretacją - staramy się ją wtłoczyć w ramy statystyki. Bo choć słusznie pisze Autor, że metafory w wierszach Leśmiana służą wyrażaniu wizji świata, w której zaciera się

[...] nie tylko granica między różnymi formami życia: ludzkiego, zwierzęcego, roślinnego, ale również granica między naturą ożywioną i nieożywioną (s. 204),

i słusznie twierdzi, iż temat śmierci pojawia się w metaforach poety częściej niż inne, to podejmowane przez niego próby ilościowej charakterystyki są po prostu od początku skazane na niepowodzenie. Na s. 187 czytamy:

Niezwykła wydaje się natomiast liczba nośników skupionych wokół tematu ŚMIERĆ - 16. [...] Najbardziej produktywny spośród tematów w przykładach zawartych w cytowanej książce Lakoffa i Johnsona WYOBRAŻENIA (IDEAS) gromadzi ich wyraźnie mniej - 9 .

Pomijając już fakt, że w przytoczonych w książce analizach znajdujemy owych nośników nie 16 lecz 15, oraz że metafor z tematem DRZEWO omawia Autor znacząco więcej (54) się sensowne, skoro jak piszą autorzy, „temat WYOBRAŻENIA” jest tylko ilustracją ich teoretycznych założeń, i skoro owe dziewięć metafor stanowi ilustrację krótkiego rozdziału zatytułowanego „Dalsze przykłady” (wyróżn.. E.T.).

Paradoksalnie, wiele zawartych $\mathrm{w}$ książce spostrzeżeń sformułowanych zostało niemal dokładnie w kategoriach kognitywnej teorii metafory. Na przykład:

[...] liczbowo przeważają podstawy odwołujące się do obecnych w języku potocznym metafor pojęciowych bądź skonwencjonalizowanych wyrażeń metaforycznych wchodzących jako całości w skład zasobu frazeologicznego języka, choć - jak to bywa z frazeologią - w różnym stopniu. Tych jest zdecydowanie najwięcej (s. 198).

Gdyby owe podstawy rozważać na płaszczyźnie pojęć i gdyby ich twórcze rozszerzenia odróżnić od metafor generycznych, można by zapewne pokazać sposób, w jaki metaforyka służy Leśmianowskiemu rozumieniu świata. Można by też wyjaśnić genezę i znaczenie tych metafor, których „zrozumienie (i wyjaśnienie) przekroczyło interpretacyjne możliwości badacza" (czyli Autora, s. 227). Bo nie chodzi tu chyba o indywidualne możliwości interpretacyjne, lecz raczej o niedostatki warsztatu. Weźmy dla przykładu

5 Notabene jest to chyba dobra ilustracja wysuwanej w monografii tezy o zainteresowaniu poety światem przyrody i jego płynnymi granicami. 
przytoczony jako ilustrację bezradności Autora fragment wiersza Leśmiana Wiedza: „W kąkolu całą dal zmieszczę!”. Angliście ta metafora przywodzi na myśl fragment znanego wiersza Williama Blake'a: To see a World In a Grain of Sand, / And a Heaven In a Wild Flower (w tłumaczeniu Zygmunta Kubiaka: „Zobaczyć świat w ziarenku piasku, / Niebiosa w jednym kwiecie z lasu"). Motyw mikrokosmosu - dostrzeganie całego świata w najmniejszej nawet rzeczy - powraca wszak w poezji wielu epok i wielu kultur. Podstawą zaś obu metafor, Leśmiana i Blake’a, jest fundamentalne dla ludzkiego poznania pojęcie zawierania się jakiejś rzeczy w innej, która służy jako pojemnik. Poetyckim rozszerzeniem natomiast - wizja zawierania się wielkiego w małym.

Jako podsumowanie, można by raz jeszcze zacytować Śmierć Buddy:

Próżno jego czepliwej ujść pragnąłem zmorze:

Jest wszędzie - jest zawczasu — i nie być nie może!,

Gdyby bowiem Leśmianowską metaforę oddzielić od oryginalnego kontekstu, można by ją z powodzeniem uznać za metaforyczny obraz badacza i przedmiotu jego badań, czyli metafory właśnie. Bo metafora - jak „pies wierny, ale uciążliwy” - towarzyszy człowiekowi wiernie, w codziennym dyskursie i w poezji, natomiast - jak starałam się pokazać - w opisie może się okazać nader uciążliwa.

\section{Literatura}

Cockiewicz W., 2011, Metaforyka Leśmiana (Analiza lingwistyczna), „Biblioteka »LingVariów«" t. 13, Kraków.

Evans V., 2009, Leksykon językoznawstwa kognitywnego, Kraków.

LAKOFF G., Johnson M., 1980/1988, Metafory w naszym życiu, Warszawa.

Lakoff G., Turner M., 1989, More than Cool Reason. Chicago.

LAKOFF G., 1991. The invariance hypothesis: is abstract reason based on image-schemas?, „Cognitive Linguistics" 1, 1, s. 39-74.

\section{A dog loyal but tiresome: on metaphor in Leśmian's poetry and beyond Summary}

The paper is a polemical commentary on Wacław Cockiewicz's monograph Metaforyka Leśmiana (Analiza lingwistyczna). [Metaphors in Leśmian's poetry (A linguistic analysis)]. It is claimed that although the author of the book rejects as inadequate the cognitive theory of metaphor developed by George Lakoff and his followers, some of his tacit assumptions actually follow its premises. On the other hand, lack of coherent methodology and erroneous treatment of metaphor as the relation of equivalence (A equals B) result in incoherent or downright incorrect interpretation of many metaphors selected for analysis. Individual items from the corpus are presented in alphabetical order, without concern for either the level of their specificity or their semantic cognation. In effect, their systematicity is often missed. Moreover, in some cases Cockiewicz finds himself unable to interpret Leśmian's metaphors, and thus his final conclusions - though intuitively correct and partially corroborated by some of the analyses - are undermined. 